\title{
Flood risk modeling using HEC-RAS and geospatial techniques
}

\author{
Suraj Kumar Singh \\ Suresh Gyan Vihar University, Ph.D, suraj.kumar@mygyanvihar.com \\ Shruti Kanga \\ Suresh Gyan Vihar University, Ph.D, shruti.kanga@mygyanvihar.com \\ Bojan Đurin \\ University North, Ph.D, bojan.durin@unin.hr \\ Nikola Kranjčić \\ University of Zagreb, Ph.D, nikola.kranjcic@gfv.unizg.hr \\ Ratan Chaurasia \\ Suresh Gyan Vihar University, M.Tech., rattan.66334@mygyanvihar.com \\ Danko Markovinović \\ University North, Ph.D, danko.markovinovic@unin.hr
}

\begin{abstract}
Flooding is a natural disaster that can ruin natural resources, cause casualties, and harm the environment. Floods are known for their deadly and destructive impacts. To predict important information about flooding, such as the extent of inundation and water surface elevations at specific locations, hydraulic modeling and Flood Inundation Mapping (FIM) must be used. A crucial tool for flood monitoring is the HEC-RAS software and remote sensing (RS) technology, in combination with geographic information systems (GIS). The primary emphasis in this discipline revolves around the definition of flood zones and the preparation of flood hazard maps for at-risk regions. This map could allocate land development priorities, and prepare services for future emergency aid and relief interventions in at-risk locations.
\end{abstract}

Key words: flood hazard, HEC-RAS, hydrological models, geospatial data, GIS

\section{Modeliranje rizika od poplava korištenjem HEC-RAS-a i geoprostornih analiza}

Sažetak: Poplave su prirodne katastrofe, koje mogu uništiti prirodne resurse, uzrokovati žrtve i naštetiti okolišu. Poznate su po svojim smrtonosnim i razornim utjecajima. Za predviđanje važnih informacija o poplavama, kao što su opseg poplave i nadmorske visine vode na određenim lokacijama, potrebno je primijeniti hidrauličko modeliranje i mapiranje poplavnih područja (FIM). Sustav za modeliranje vodotoka (HEC-RAS) i tehnologije daljinskog istraživanja (RS), u kombinaciji s geografskim informacijskim sustavima (GIS), ključni su za praćenje poplava. Primarni naglasak u ovom radu je na definiranju poplavnih zona i izradi karata opasnosti od poplava za rizična područja. Ovaj model može dodijeliti prioritete razvoja prostora $i$ pripremiti službe za buduću hitnu pomoć i intervencije na rizičnim mjestima.

Ključne riječi: opasnost od poplava, HEC-RAS, hidrološki modeli, geoprostorni podaci, GIS

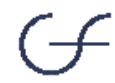


Singh, S. K., Kanga, S., Đurin, B., Kranjčić, N., Chaurasia, R., Markovinović, D.

Flood risk modeling using HEC-RAS and geospatial techniques

\section{INTRODUCTION}

Floods are naturally occurring hazards that become a disaster when they endanger humans and their assets. Floods are one of the most extensive, frequently reoccurring natural disasters. According to the dictionary, a flood can be defined as "an overflow of a large amount of water beyond its normal limits, especially over what is normally dry land." Flooding is the consequence of heavy or non-stop rainfall exceeding the absorptive capacity of soil and land. This causes water to overflow its banks into adjacent lands. The frequent occurrence of flood can be attributed to extreme hydro-meteorological action and geomorphologic agents such as permeability and soil stability, vegetation covers and geomorphic characteristics of the river basin, as well as inadequate carrying capacity of the rivers, which become the cause for the occurrence of flood. Human activities have also contributed to the increase in magnitude and frequency of floods. Since time immemorial, humans have always sought their development along fertile river banks. Many communities have flourished along floodplains regions because of their productive land transportation facility. But, ever-increasing population and human settlement along with the growth of rural and urban zone in rivers edge and flood plains, without interpretation and giving awareness to the dynamical and hydrological condition of the upstream area of the rivers have greatly amplified flood risk and exposed the population to flood hazard with the constant threat of flooding leading to the risk of life and property. The pressure of population growth and shortage of lands promotes the development of settlement on the flood plain, deforestation and removal of root system increase runoff which contributes to flooding during the rainy season, failure to maintain and manage drainage systems, dams' protection in vulnerable areas also contributes to flooding.

Geographically floods can be group into three main kinds of flooding. Riverine flooding occurs when heavy precipitation affects the watercourse. Urban flood inundating occurs when surface runoff surges the size of drainage arrangement, which arises when non-stop precipitation movement on drains with imperfect water runoff ability and coastal water inundating occur when heavy precipitation on internal encounters storm flows from the sea. The influence of happening natural disasters universally is becoming more and more severe. Over the last years, there has been a growth in the amount of calamity stated, which has a deadly impact on the worldwide economy and the number of persons involved. Among the natural disaster, flood catastrophic is considered one of the costliest, most devastating and most frequent with tremendous ability to cause fatalities, damages, assets damage, and financial losses to civilization. According to the magnitude and extent of the flood, it has been classified into minor and significant. In minor floods, water levels are usually confined to flood plain along the river channel. Flood water is generally low, and there may not be perceptible flow. When there is a severe break in the dam, embankment discharge of water in reservoirs, lakes, or rivers is also responsible for causing a significant flood.

According to United Nations (UN) estimation, approximately $40 \%$ of the world population resides within rivers and lakes basins that encompass two or more countries very dependent on the available freshwater. A recent report by the UN revealed that over the last 20 years, about 157,000 persons have expired due to floods. The statement also stated that between 1995 and 2015, floods affected nearly 2.3 billion people, which accounts for $56 \%$ of all those affected by climate-related disasters. Flood hazard risk modeling is rapidly developing and a very dynamic domain. The rapid development of computing power and various technological applications gave a new direction to this domain. Flood hazard risk modeling is very essential for the flood plain management. There are so many software programs like ArcMap, Erdas Imagine, HEC-RAS, HEC-HMS, etc., which are used for the flood hazard risk modeling. The flood plains in common are those most endangered by flooding and are, therefore, "floodprone" or hazardous to developmental activities. For recognition of flood danger regions and 
Singh, S. K., Kanga, S., Đurin, B., Kranjčić, N., Chaurasia, R., Markovinović, D.

Flood risk modeling using HEC-RAS and geospatial techniques

organization in direction to decrease flood harm, flood zone maps have been organized and used extensively in the flood plain management studies. For flood hazard risk modeling, high-resolution data is essential to classify the land topographies of the learning area. With the help of high-resolution data, categorize the imageries and make LULC maps for flood hazard risk modeling. The high-resolution data describe the situation of the river; how much urban area is accessible nearby the river. Hence, it is helpful to understand if in case the flood comes how much metropolitan area will be affected can be determined, and essential methods can be taken to reduce the result of a flood. High-resolution DEM is necessary for the flood hazard risk modeling with the help of the DEM to get elevation values of the study area, which is essential for the flood hazard risk modeling.

Flood hazard zoning maps deliver evidence of the flood-prone region. Flood hazard zoning maps can be an effective instrument to reduce harm by establishing proper flood protection plans; with the help of remote sensing and GIS (Geographical Information System), information about flood-prone areas will be mapped. The satellite images will be used to create Land Use and Land Cover maps (LULC). This LULC change is used to generate flood Hydrographs in "HEC-HMS". The impact of LULC change on flood peak discharge and runoff volume is assessed for different flow conditions. Flood plain and flood hazard maps for the different land-use scenarios are developed by integrating hydrologic and hydraulic models with GIS and Remote Sensing. The flood plain maps derived from the study can be used as inputs for flood risk hazard zonation proper planning and flood forecasting.

\section{STUDY AREA}

The River Varuna is an intermittent river, with lean flow conditions prevailing during the nonmonsoon season. It originates at $25^{\circ} 23^{\prime} 36.24$ "N \& 82 $37^{\prime} 36.98 " E$ near district Bhadohi (UP) and flows East-to-Southeast direction for approximately $100 \mathrm{~km}$, and confluences at $25^{\circ} 19^{\prime} 47.02^{\prime \prime} \mathrm{N} \& 83^{\circ} 2^{\prime} 37.10^{\prime \prime} \mathrm{E}$ Adikeshwar Ghat in Varanasi with River Ganges in downstream of Varanasi (Figure 1). The climate of the area is mild and generally warm, situated in the Northern Part of India. Summers are as hot as $45^{\circ} \mathrm{C}$ and humid. The average annual rainfall in the area is about $998 \mathrm{~mm}$, out of which the major part is received during the monsoon period. The primary land use is in agriculture, and there is no significant forest cover. The soil of the area is sandy loam to loamy soil. River Varuna has a total length of approximately $100 \mathrm{~km}$. 
Singh, S. K., Kanga, S., Đurin, B., Kranjčić, N., Chaurasia, R., Markovinović, D.

Flood risk modeling using HEC-RAS and geospatial techniques
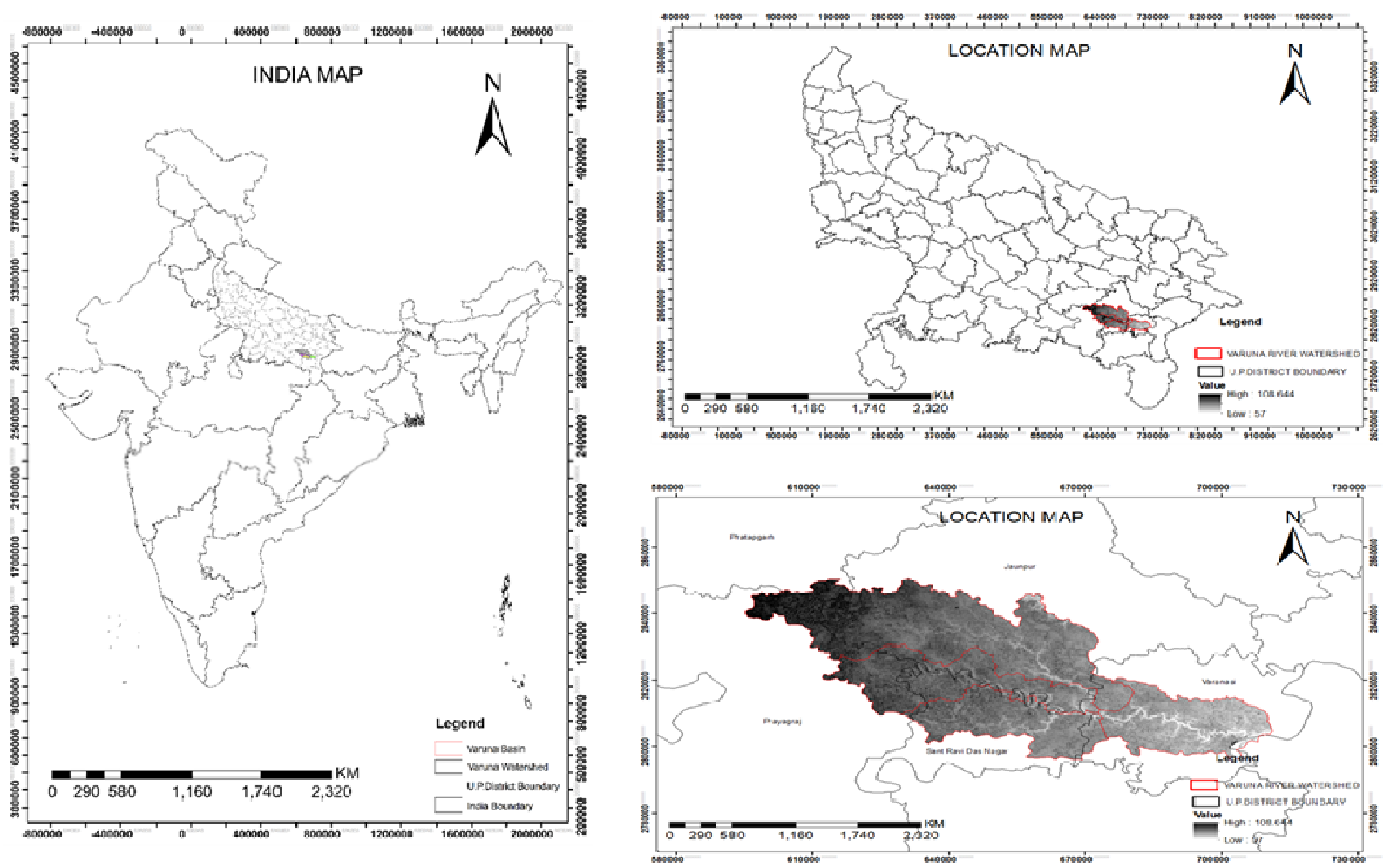

Figure 1. Study area map

\section{MATERIALS AND METHODS}

The world's primary approach to flood hazard assessment is fundamental non-structural modeling. It is a way to model floods to anticipate the severity of a flood before it happens. It gives decision-makers the tools they need to develop a flood-mitigation strategy even before a flood takes place. Before flooding simulations can be conducted accurately, a detailed landscape must be constructed in the computer system. Digital Elevation Models (DEMs) are options for creating a GIS representation of the terrain. Accurate flood modeling is dependent on the precise elevation models provided by the digital terrain models. Elevation point readings were used to digitally depict the earth's surface using the Shuttle Radar Topography Mission (SRTM) Digital Elevation Model (DEM). SRTM data from the Earth Explorer website, which provided DEM with a resolution of $30 \mathrm{~m}$, was used for the investigation. The Central Water Commission's (CWC) data on discharges for the study was obtained from New Delhi. The roughness parameter, Manning's $n$ value, is important in the $1 \mathrm{D}$ model to solve the estimated water surface profile. Manning's $n$ varies greatly depending on parameters such as surface roughness, vegetation, channel irregularities, channel alignment, scour and deposition, obstacles, channel size and shape, discharge stage, seasonal fluctuations, temperature, and suspended material and bed load.

Environmental Systems Research Institute's (ESRI) ArcGIS is a powerful and easy-touse mapping, data visualization, and spatial analysis application. Several spatial analytical tasks, such as grid-based raster data processing, modeling, visualization, and interpretation, can be carried out using the Spatial Analyst extension. GIS has demonstrated an excellent tool for floodplain management, including operations such as base mapping, topographic mapping, and post-disaster verification of mapped floodplain extents and depths. HEC-RAS, a one-dimensional hydraulic flow model, created by the U.S. Army Corps of Engineers 
(USACE), was utilized in the current research. HEC-RAS uses many factors for stream channel hydraulic analysis and water flow. To determine the various cross-sections along the stream, these criteria are employed. Every segment is classified into a left bank, main channel, and right bank based on the locations of the stream banks in each cross-section. Figure 2 shows a flowchart that illustrates the study's methodology.

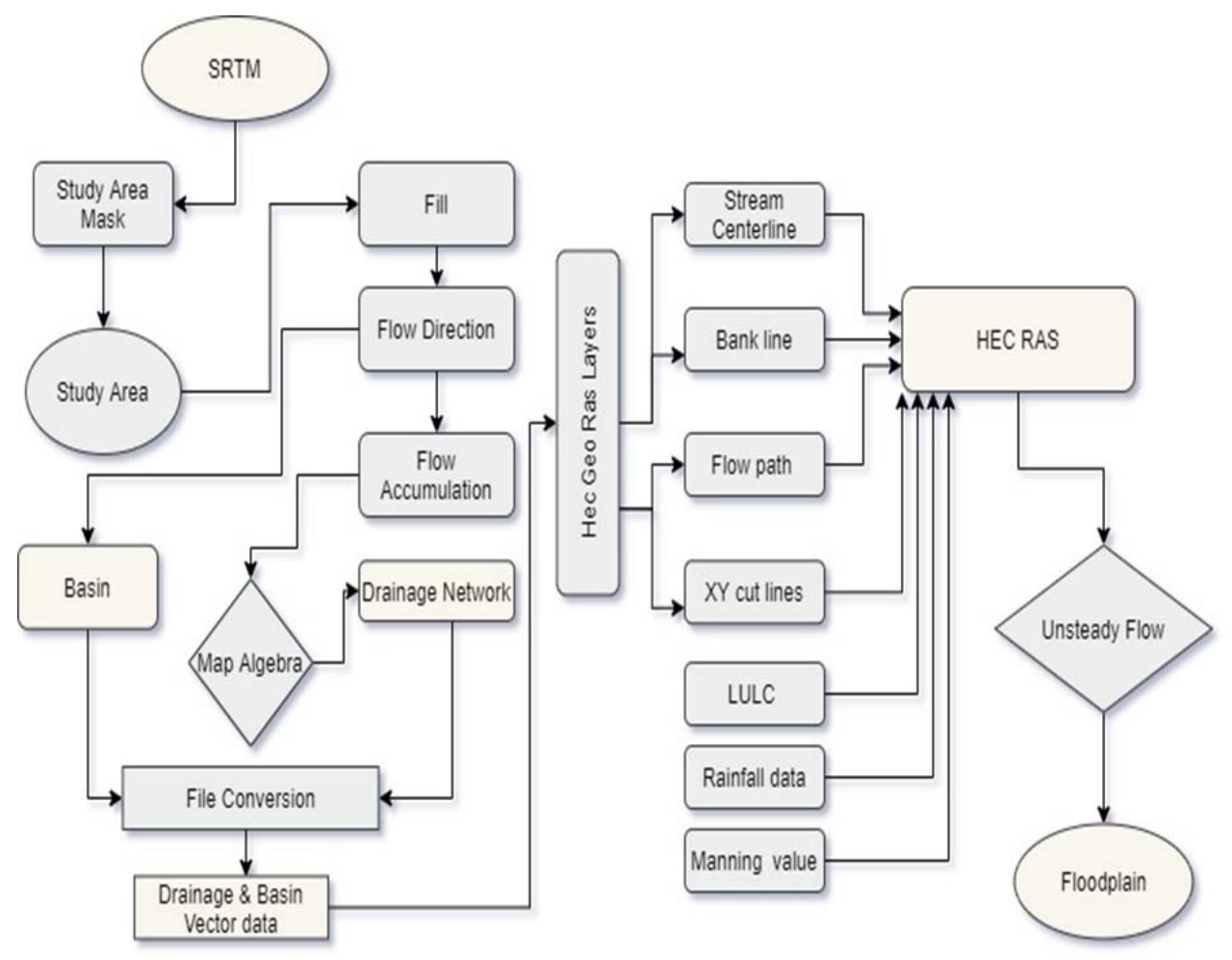

Figure 2. Flowchart - the study's methodology

\section{RESULTS AND DISCUSSION}

\subsection{Watershed Modeling}

The SRTM DEM (Shuttle Radar Topography Mission) is a data set created by NASA and the National Geospatial-Intelligence Agency (NGA) collaborating with the German and Italian space agencies. In February 2000, the Endeavour shuttle mission began. This project's goal was to acquire global elevation data. A modified radar system was installed on Endeavour to conduct interferometry during a mission that lasted 11 days. It was possible to collect data ignoring day and weather thanks to interferometry and the frequencies employed (more than 90 percent of the area was acquired twice and nearly 50 percent three times). The process of retrieving data yielded the most complete near-global high-resolution and high-elevation accuracy Earth database. The United States Geological Survey (USGS) has started to distribute global Shuttle Radar Topography Mission (SRTM) elevation data at 1 arc-second (30-meter) resolution (Figure 3). 
Singh, S. K., Kanga, S., Đurin, B., Kranjčić, N., Chaurasia, R., Markovinović, D.

Flood risk modeling using HEC-RAS and geospatial techniques

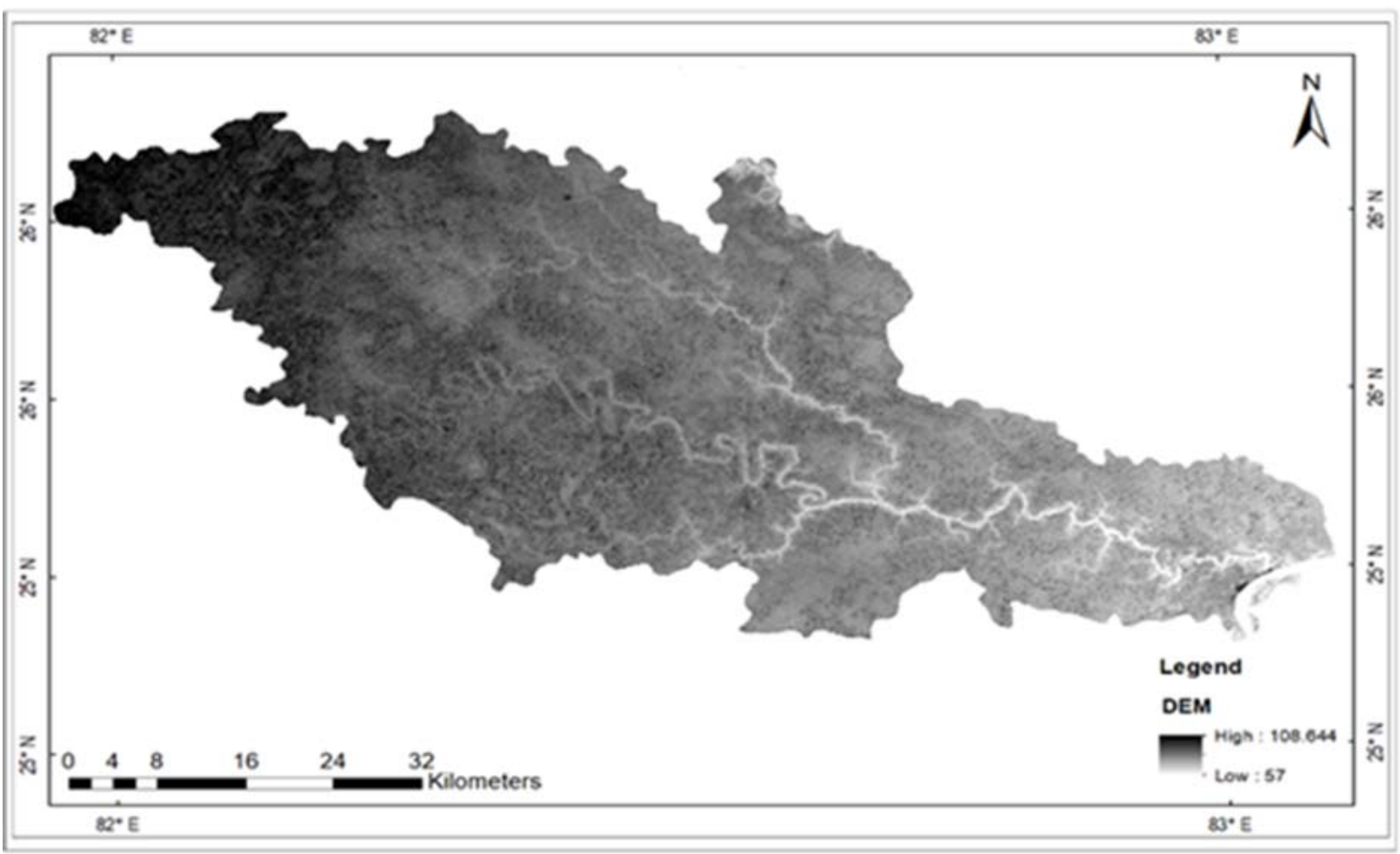

Figure 3. DEM Map

Within the analysis frame, drainage basins are identified by identifying ridgelines between basins. The input flow direction raster is investigated to identify all of the drainage basins containing related cells. A drainage basin is built by determining the locations where water would flow out of the raster, along with the sinks. To identify the contributing area of each pour point, the area above the pour point must also be known. Raster of drainage basins comes from this. The most significant results will be obtained by running the algorithm with the Force all edge cells to flow outward option (FORCE in Python) enabled. Each cell in the raster belongs to a basin, regardless of the size of the basin. No cells beneath it has a specified drainage path.

Hence a sink is a cell. The boundary cell for the lowest elevation in the contributing area of a sink is the pour point. If the sink were filled with water, it would drain here. The z-limit controls which sinks will be filled and which will remain untouched based on the greatest difference between the depth of a sink and the pour point (Figure 4). The z-limit is not the maximum depth to which a sink will be filled. For instance, a location having a pour point at 210 feet in elevation and the deepest point at 204 feet should be considered (a difference of 6 feet). Setting the z-limit to 8 will make this particular sink fill up. The z-limit of 4 prevents this sink from filling since it is too deep and hence it is considered a legitimate sink. Pour points that reach the lower bounds of the z-limit will fill the sinks below the z-limit and beneath their lowest neighbor. How long the processing takes will depend on the number of sinks discovered using the z-limit. As the number of sinks increases, the processing time will be lengthened. The Sink tool can be used in advance of the Fill tool to figure out the number of sinks and where they are located. It is helpful to know the sink depths to establish the proper z-limit. Additionally, Fill can be employed to eliminate high points. 
Singh, S. K., Kanga, S., Đurin, B., Kranjčić, N., Chaurasia, R., Markovinović, D.

Flood risk modeling using HEC-RAS and geospatial techniques

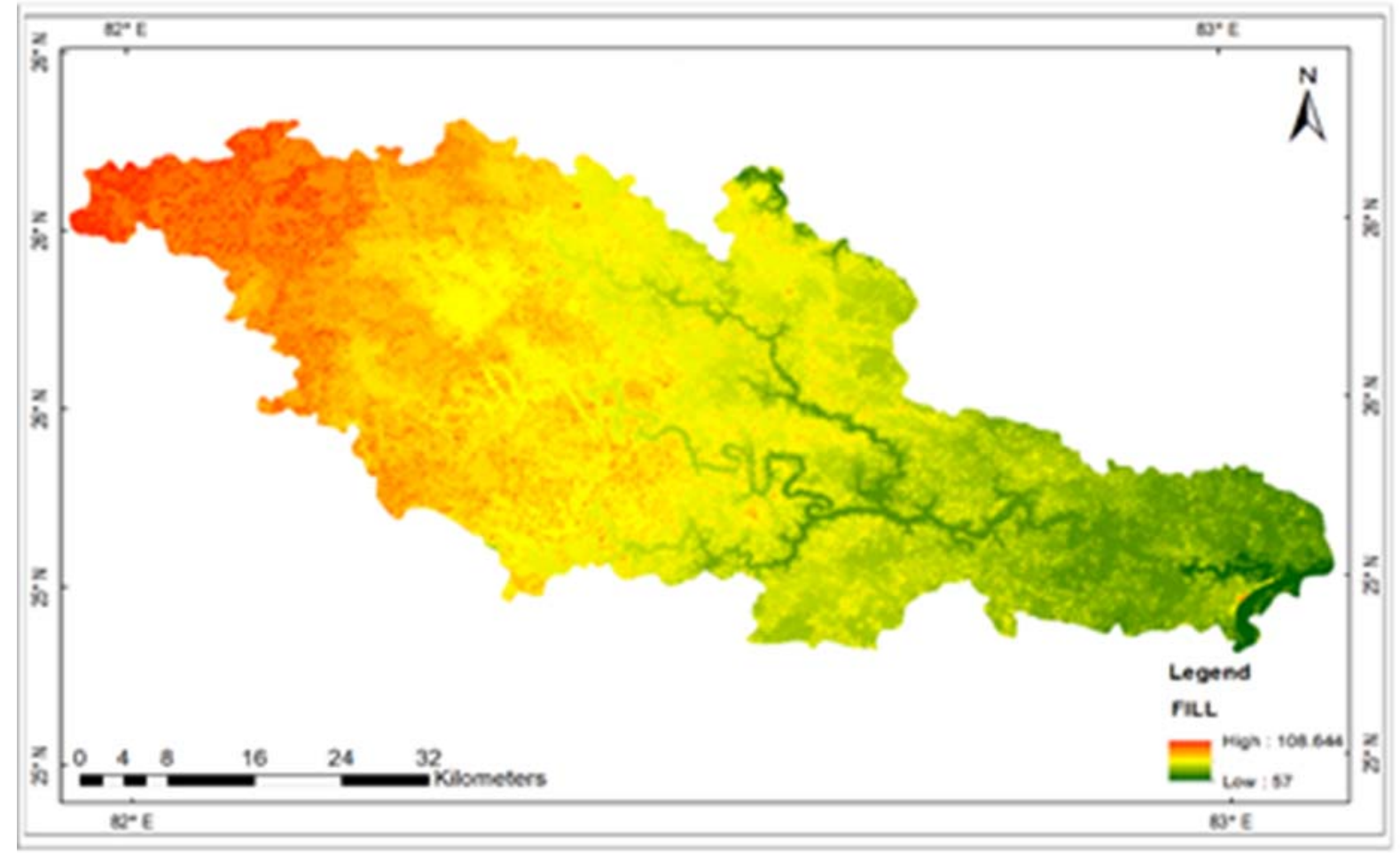

Figure 4. Fill Map

A z-limit can also be used for this operation (Figure 5). All peaks will be eliminated if no $z$-limit is defined. If given, any peaks with a z-value variation between the peak and its closest neighbor higher than the z-limit will not be deleted. The outcome of the Flow Accumulation algorithm is a grid where the accumulated flow to each cell is given by adding the flow contributions of all enclosures which flow into that downslope cell. Cells with an unknown flow direction receive flow; they will not supply any flow to other cells. If a cell in the flow direction raster has a value other than $1,2,4,8,16,32,64$, or 128 , it is deemed to have an unknown flow direction. Each cell in the output raster has an accumulation flow based on the number of cells flowing into it. This data excludes the current processing cell. Areas of concentrated flow can be identified using output cells with high flow accumulation. The zeroflow cells are high points on the local topography and can be used to detect ridges. If you do not use the Flow Direction tool to construct the input flow raster, you may have to deal with flow loops. Flow Accumulation will never be complete if the flow loop happens because it will go into an indefinite loop. The Flow Accumulation tool fails to comply with the Compression environment option (Figure 6). The final output raster will be in the form of uncompressed data. Flow Direction tool output is a raster integer (values 1 to 255) that is produced by a combination of input rasters. 
Singh, S. K., Kanga, S., Đurin, B., Kranjčić, N., Chaurasia, R., Markovinović, D.

Flood risk modeling using HEC-RAS and geospatial techniques

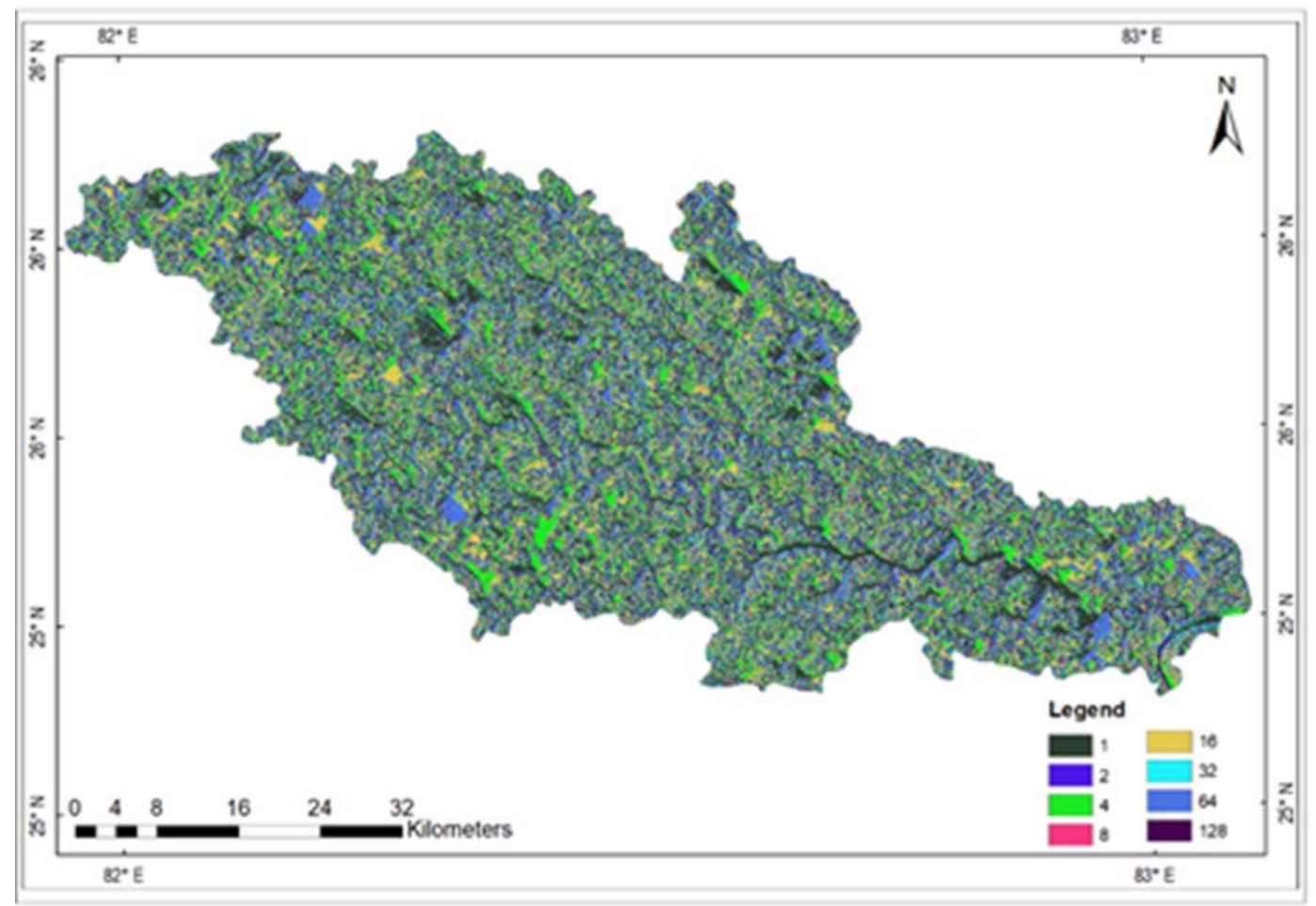

Figure 5. Flow Direction Map

This feature removes unwanted, single-cell sinks that are deemed noise. A sink is characterized by having a cell in which the z-value varies in several directions, while the cell is part of a sink if it meets this condition. The values of that cell in the output flow raster will be calculated by summing the output directions. If the change in z-value is the same to the right and down ( 1 and 4$)$, then the flow direction for that cell is $1+4=5$. Sinks can be highlighted with the Sink tool in cells that have an unknown flow direction. A cell with the same change in z-value in many directions and that is not part of a sink gets its flow direction allocated with a lookup table that defines the most likely direction. The z-value drop raster is created by dividing the z-value difference between cell centers by the path length between them, given as a percentage. The \% slope between adjacent cells is equivalent to this. The distance between cells will get shorter as it traverses a flat area. This produces a graph showing the path of steepest descent from each cell, which shows the percentage increase. To increase performance, the smooth surface approximation for drop raster values $(1.41421$ * cell size) is $1.5^{*}$ cell size. In the standard-setting (NORMAL in Python), a cell on the border of the surface raster will flow inward to the inner cell, whose z-value drops fastest. If the drop is less than or equal to zero, the cell will flow out of the surface raster. The Flow Length tool is commonly used to determine the length of the longest flow channel in a basin (Figure 6). The time of concentration of a basin is frequently calculated with this procedure. To do this, UPSTREAM is used. It may also be used to construct distance-area maps of rain and runoff events using raster weight as a resistance to downhill flow. For the output raster of the flow length, the value type is a floating point. The flow direction of a sink cannot be assigned one of the eight valid values in a flow direction raster. This can occur if the processing cell is surrounded by cells of higher elevation, or if two cells flow into each other, forming a two-cell loop. 
Singh, S. K., Kanga, S., Đurin, B., Kranjčić, N., Chaurasia, R., Markovinović, D.

Flood risk modeling using HEC-RAS and geospatial techniques

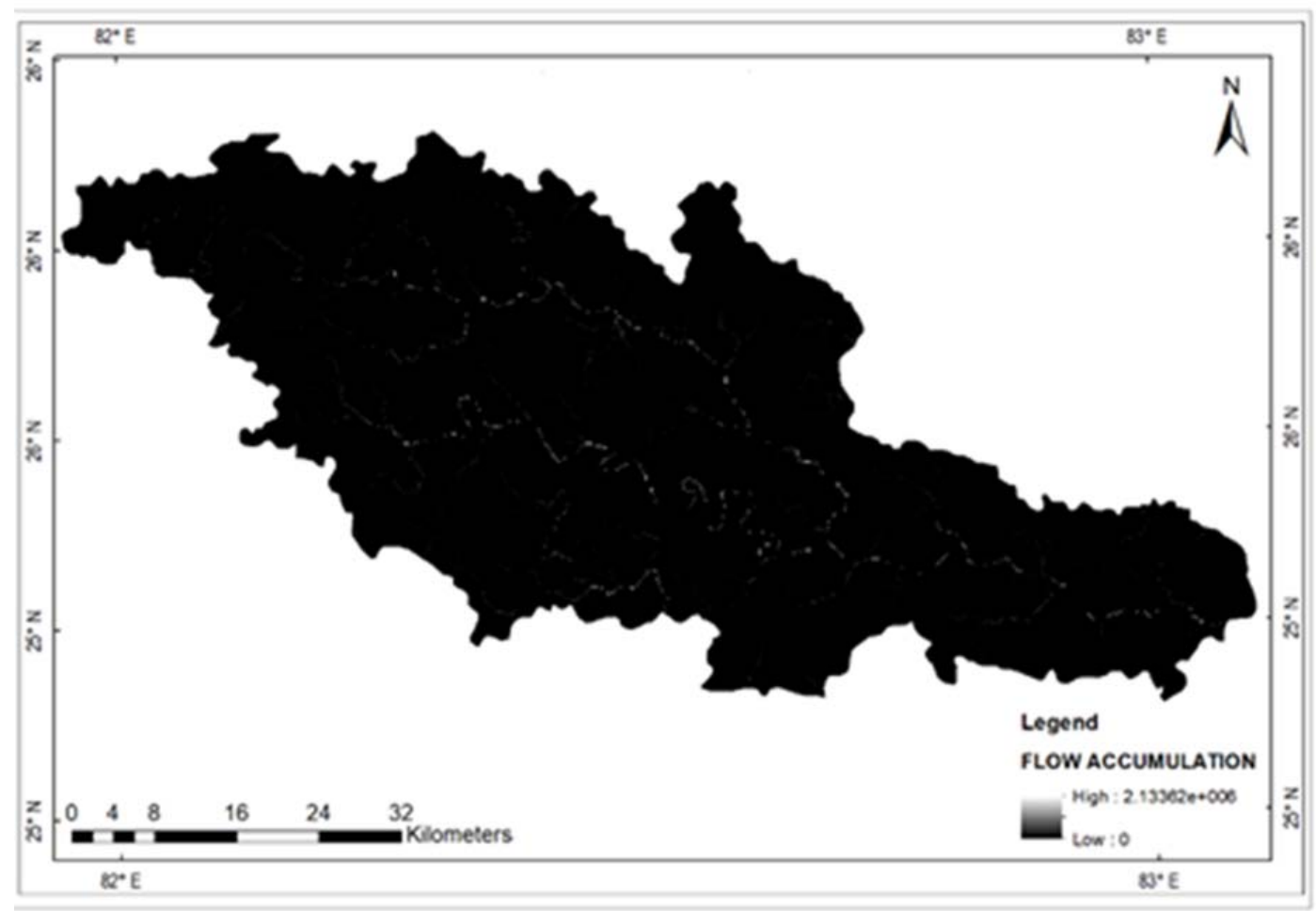

Figure 6. Flow accumulation Map

The result of the Sink tool is a grid of integers, with each sink getting a unique value. Sinks are denoted by the number between one and the total number of sinks. If you start with a shared surface, the result of Stream Order will be of greater quality. Since the results of the raster stream are based on a rasterized stream dataset, the cell-to-cell direction may not match the position of stream cells. A stream network can be created using the findings of the flow accumulation tool by setting a threshold value and selecting the cells that exceed that value. Additionally, the flow of more than 100 cells can be used to identify the network of streams (Figure 7). To build a flow accumulation raster with a value of 100 or more in the stream network, use the Con or Set Null tool (NoData). Using the generated stream network, Stream Link and Stream to Feature can be employed. The value of each watershed will be determined from the input raster, or feature pours point data. In the case of a raster dataset, the cell values will be utilized for the pour point. The values will be retrieved from the designated field if the pour point is defined as a point feature dataset. Earlier usage of the Snap Pour Point tool can help you get a more accurate reading of the cells with the highest accumulated flow. 
Singh, S. K., Kanga, S., Đurin, B., Kranjčić, N., Chaurasia, R., Markovinović, D.

Flood risk modeling using HEC-RAS and geospatial techniques

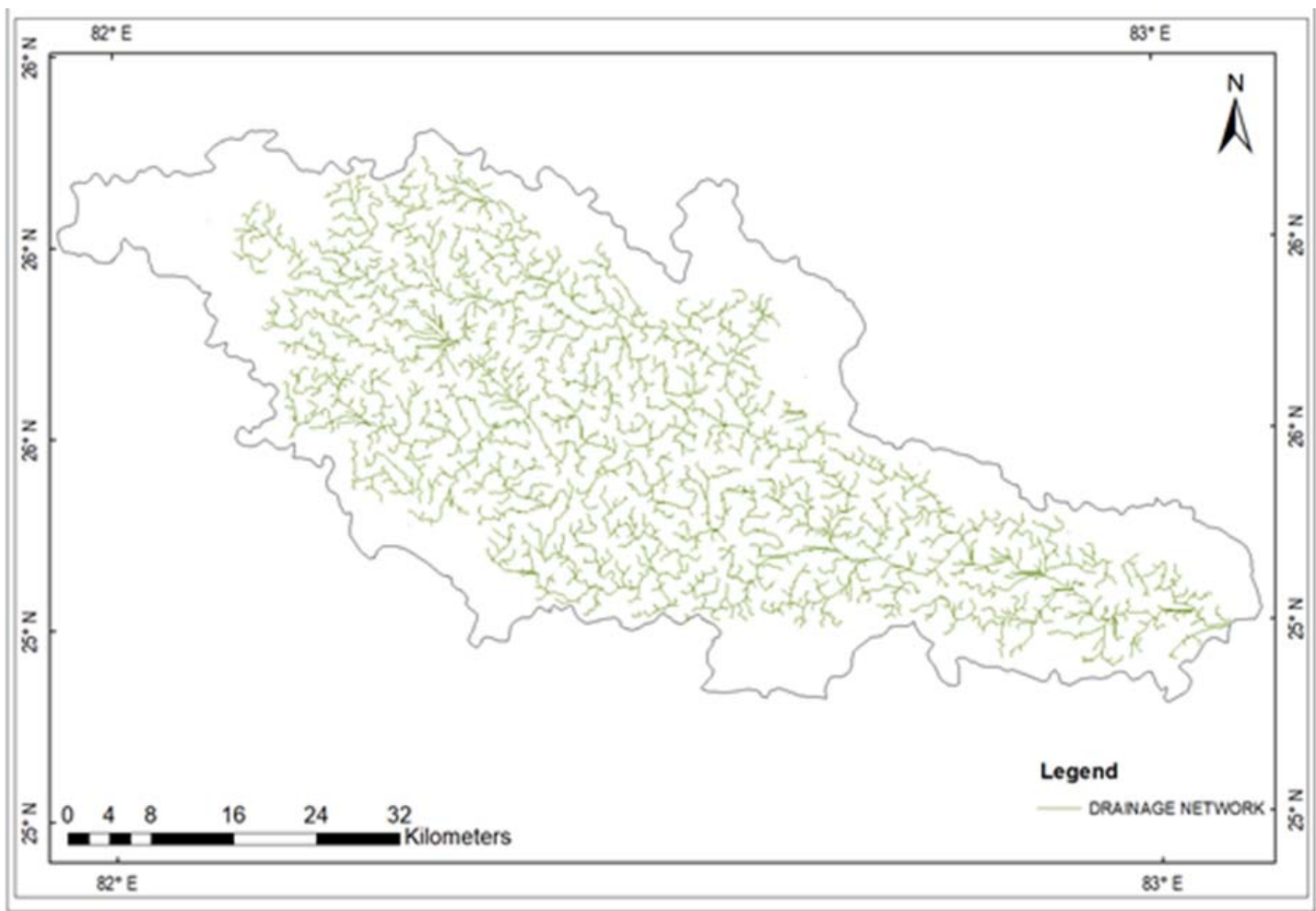

Figure 7. Drainage network map

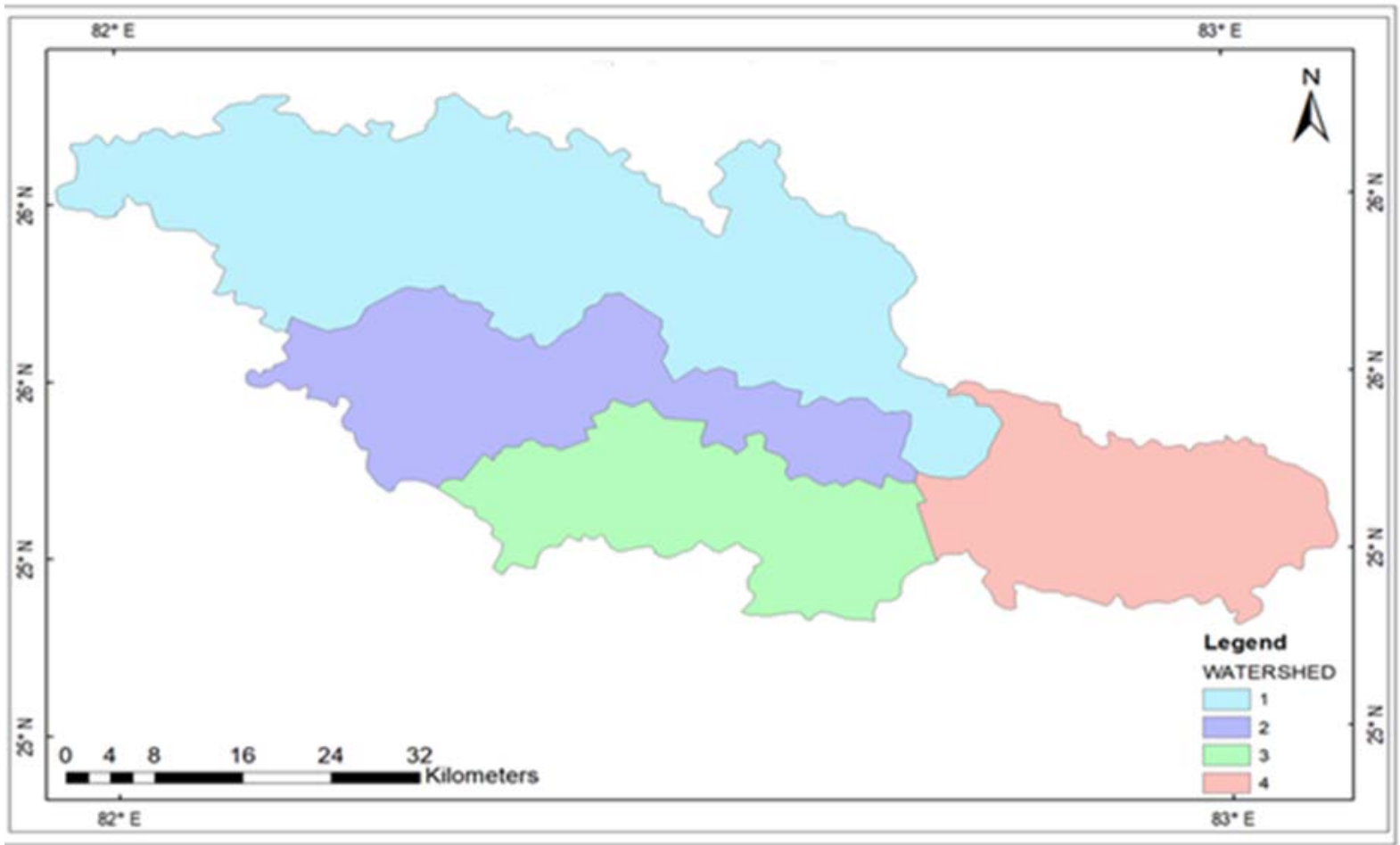

Figure 8. Watershed Map

When providing feature data for the input pour point locations, the default field will be the first accessible valid field. If there are no acceptable fields, the default field is Object ID (e.g. 
Singh, S. K., Kanga, S., Đurin, B., Kranjčić, N., Chaurasia, R., Markovinović, D.

Flood risk modeling using HEC-RAS and geospatial techniques

OID or FID). Using the processing tool of the HEC-GEO-HMS, generate a Build Walls of the DEM, fill the sinks of the DEM, create a Flow direction, generate flow accumulation, define the streams, create a stream segmentation, delineate the catchment grid of the area, processing the catchment polygon, generate drainage lines of area, create the adjoin catchment of the area (Figure 8).

\subsection{Soil and LULC modeling}

After the set-up of the project area and project watershed, delineation of the longest flow path of the river with the help of the characteristics tool of HEC-GEO-HMS, after the longest flow path delineation, calculation of the CN Grid value was performed. The parameters to calculate the CN Grid value are the soil map and the LULC map of the project area. ERDAS, Image software was used to classify the Landsat 8 images using a supervised classification tool, and four classes, i.e. built-up, forest, agriculture, and waterbody, were delineated. After that, conversion of the LULC map in a Polygon was done with the help of ArcGIS conversion tools. Reclassified soil map in the form of HSG (Hydrological Soil Group) determine the HSG for each pixel from the soil map that has been provided based on the soil property. Create a soil map of the study area and classify the soil according to the HSG (Hydrological Soil Group).

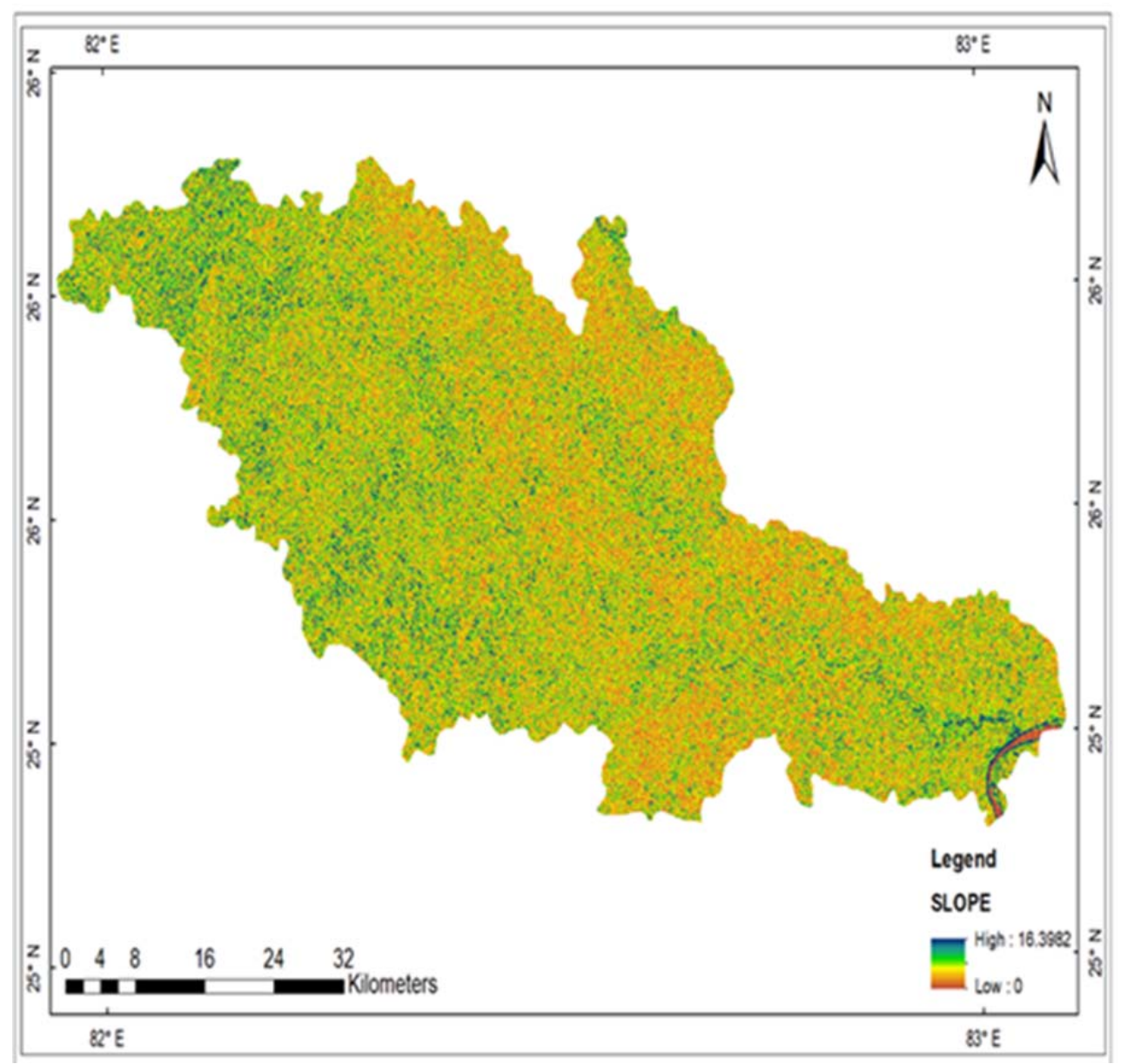

Figure 9. Slope Map 
Singh, S. K., Kanga, S., Đurin, B., Kranjčić, N., Chaurasia, R., Markovinović, D.

Flood risk modeling using HEC-RAS and geospatial techniques

This map represents the slope of the study area (Figure 9), Varanasi district has a flat terrain. In some areas, the slope is there, but most area comes under a flat terrain. This map represents the potential runoff of the Varanasi district. It defines the quantity of water discharge in surface streams. It helps get an idea about the water flow on a surface, which area will be more affected by the heavy rainfall.

\subsection{HEC-RAS Modeling}

For HEC-RAS modeling, create a geometry of the river through HEC-GEO-RAS. HEC-GEORAS is software used for the geometry of the river. This software is essential to run because the output of this software is an input of the HEC-RAS software. HEC-GEO-RAS software is easy to handle. The interface of this software is ArcGIS. In this software, there is a RAS geometry tool used to create a geometry of the river (Figure 10).

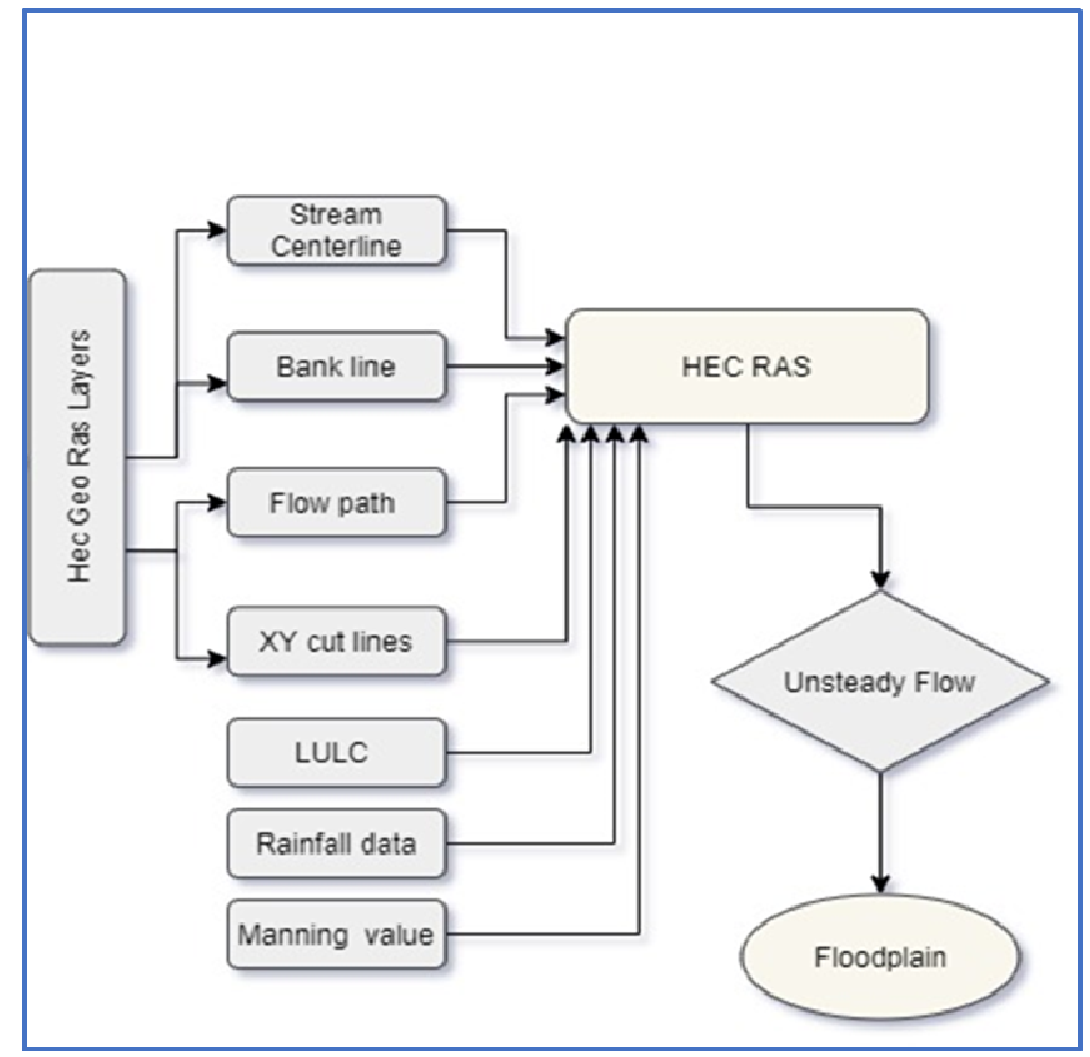

Figure 10. Methodology adopted for HEC-RAS modeling

In HEC-GEO-RAS software, generate geometry or Cross Section of the river through RAS Geometry tool. Create a Centerline of the river, which should be digitized in a proper manner. Overlay it on a high-resolution data or Google Earth. When the centerline is digitized, next to digitize a Bank Lines of the river, Bank Lines are parallel to the Centerline Banks Lines. When Bank Lines digitize prefer to digitize a riverbed outline of the Stream Centerlines, both sides of the river Banks Lines should be appropriately digitized. When the Flow Path has been digitized, the color of the river and the color of the Flow Path is the same. Create a Flow Path parallel to the Banks Lines. Next step is construction a XS Cutlines on the river. The XS Cutlines are created through software ${ }^{11}$. XS Cutlines should not intersect with each other. Otherwise, it generates an error when the model was performed. 
Singh, S. K., Kanga, S., Đurin, B., Kranjčić, N., Chaurasia, R., Markovinović, D.

Flood risk modeling using HEC-RAS and geospatial techniques

After all this process, the Cross-Section of the River is generated, which is required for the Hydraulic Modeling. Export the Cross-Section of the river in a GIS format and import it in HEC-RAS software, which shows the river's Geometry. Producing a Cross-Section of a river channel is an essential river fieldwork skill. The first stage is to measure the width and depth of the river. The data gathered can then be plotted to create a scale diagram of the Cross Section or find the Cross-Section area and wetted perimeter of the river. Cross Section represents the change in slope, shape, roughness, structure of the main channel, and adjoining flood plain; these cross-section areas are drawn based on DEM. Cross-Section is depicted from left to right while looking downstream. This data can be used to create a visual representation of what the river looks like. People can use hand tools such as a type measure and surveying pole to measure the Cross-Section of a river. However, organizations such as the United States Geological Survey use modern methods. These include GPS data, Laser Range-Finders and Echo Sounders. The information compiled from multiple river Cross-Section can be used for research projects to determine Hydraulic flow (Figure 11).

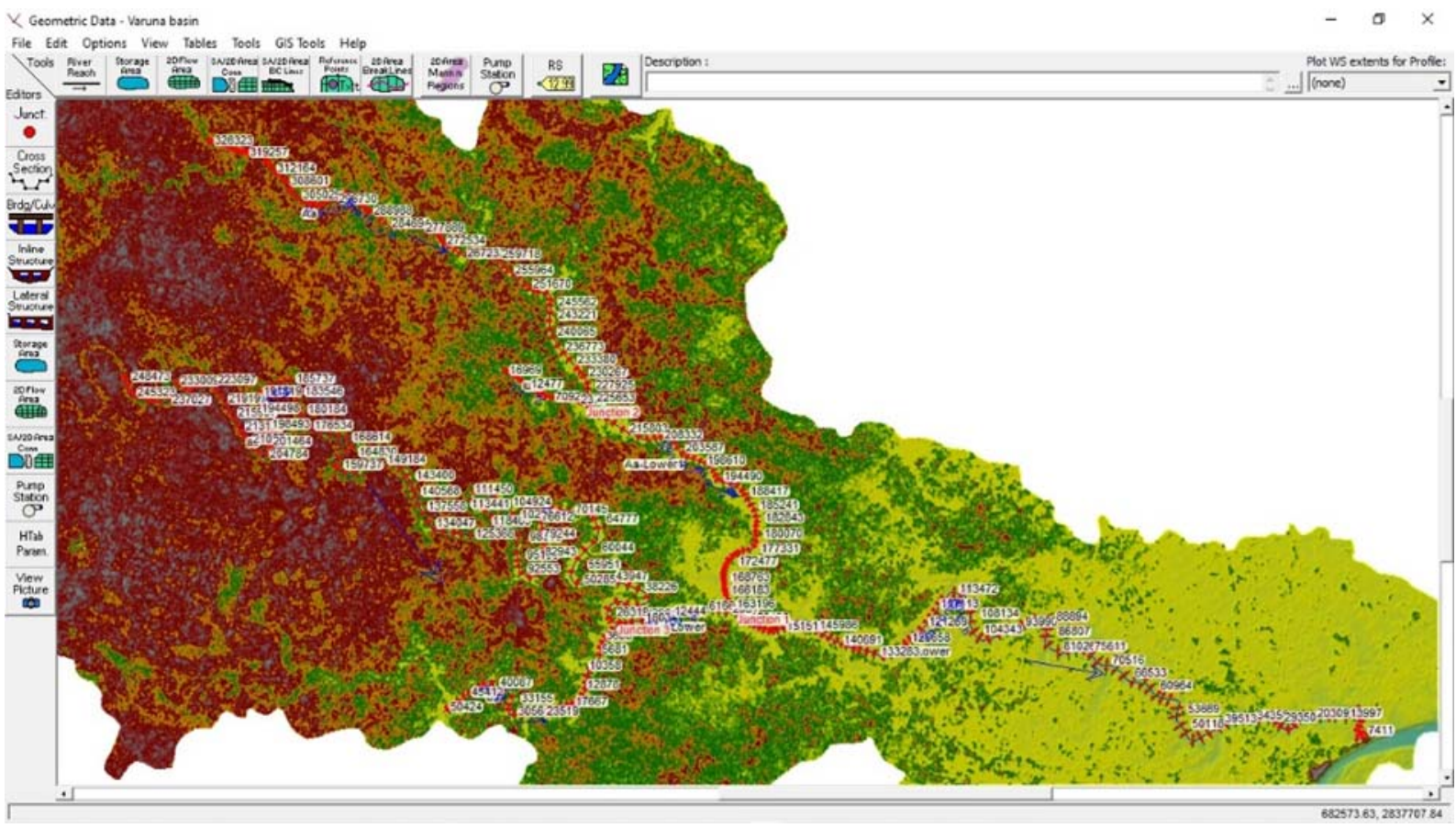

Figure 11. Profile of the Varuna River

HEC-RAS flood modeling result revealed that the area at risk to flooding would be 932 , 1511, 2031, and 3147 ha, corresponding to 2-, 5-, 10-, and 20-year return flood, respectively, and concerning the 2-year flood, the increased flooded area is $62 \%$ (5 years), $118 \%$ (10 years), and $238 \%$ (20 years), respectively. To perform ward-wise impact analysis, the modeled flood extent layer of each return period was intersected with the ward boundary. If a flood will come into this area, the urban area is so much affected because the Varuna river is close to the urban area of Varanasi city. Slums area are so much affected by this flood, because slums areas are present on the riverbed of the Varuna river in the summer season. The water level of the river is not high, riverbed of the Varuna river is dry, but in monsoon season, rainfall is high, and the drainage of the Varanasi city is blocked so it results in flooding. Through these models, generate a flood-prone area map that shows how much area will be affected. With the help of the runoff coefficient, a hydrologist can calculate how 
Singh, S. K., Kanga, S., Đurin, B., Kranjčić, N., Chaurasia, R., Markovinović, D.

Flood risk modeling using HEC-RAS and geospatial techniques

much water passes over a given area per second. The CN Grid and Slope map show an idea in which area more water is passed over time. If the slope of the area is high, the runoff of the water is also increased, while if the slope of the area is gentle, runoff water is less. These maps represent the flood-prone area of Varanasi city (figure 12-13). With the help of this map, get an idea of how much area will be affected, which helps minimize the damages that occur at a time of the flood.

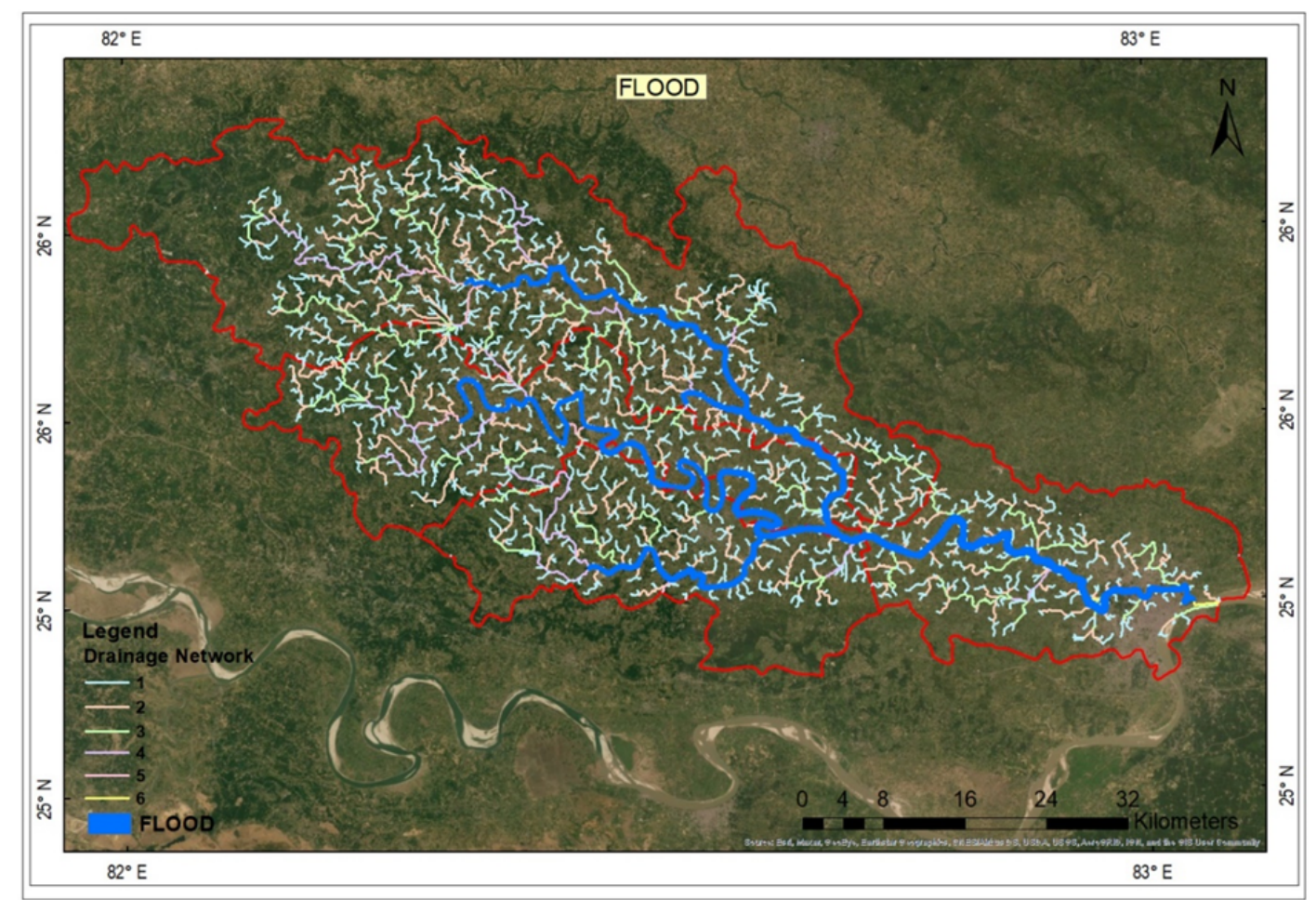

Figure 12. Map representing spatial distribution of water flow at the time of flood 
Singh, S. K., Kanga, S., Đurin, B., Kranjčić, N., Chaurasia, R., Markovinović, D.

Flood risk modeling using HEC-RAS and geospatial techniques

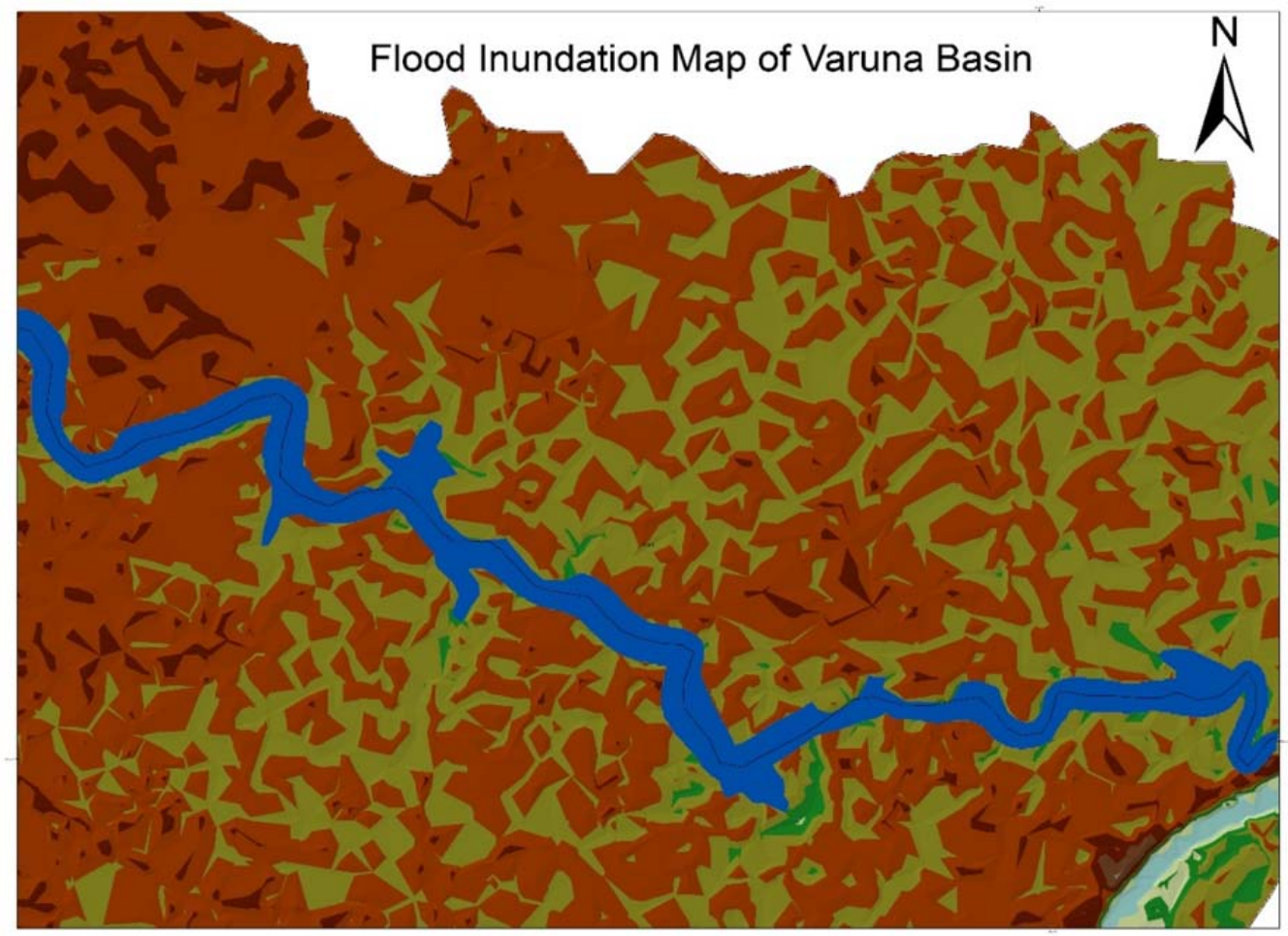

Figure 13. Flood-prone area map at selected location

\section{CONCLUSION}

The current study has used a combination of the hydrological model "(HEC-RAS)" and GISbased analytical framework to measure flood risk and likely impact with a specific repetition prospect, obtained by frequency analysis. The most dangerous flood-prone sub-area (Varanasi Sadar) in the Varanasi City Municipal Corporation is nominated as a case study. Seeing the existing condition, flood inundation modeling is performed, and it shows that substantial flooding effect starts at an extreme discharge possibility of $1000 \mathrm{~m}^{3} / \mathrm{s}$ against a 5year return period. The predictable effect slowly rises with 10- and 20-year return flood. In terms of possible harm and land use vulnerability, the most likely affected areas belong to built-up use, followed by profitable, communal, and semi-public use. Usually, flood risk differs by place and condition, so in the case of Varanasi City, on the explanation of its location and hydro-meteorological features, to some amount, flood risk is unavoidable. Despite these natural factors, with the benefit of flood-risk modeling using the geospatial approach, the present study showed that flood accumulation modeling and resultant mapping could be used as a basis for flood-risk management at the city or municipality level in the following ways: It can aid local specialists and agencies in causal place, and provision of land uses or progress type, complying with different flood-risk zone while creating local development plans. It allows the modeling of situations for flood strength and the possible effect on people and infrastructure. These situations can help express version measures like access to critical facilities, release housings, and clearing ways. 
Singh, S. K., Kanga, S., Đurin, B., Kranjčić, N., Chaurasia, R., Markovinović, D.

Flood risk modeling using HEC-RAS and geospatial techniques

\section{REFERENCES}

1. Abdessamed, D., Abderrazak, B. Coupling HEC-RAS and HEC-HMS in rainfall-runoff modeling and evaluating floodplain inundation maps in arid environments: case study of Ain Sefra city, Ksour Mountain. SW of Algeria. Environ Earth Sci 78, 586. https://doi.org/10.1007/s12665-019-8604-6, 2019.

2. Ahmed, E., Salwa, S., Taoufik, H., Ichrak, K., Fadila, D., Hamadi, R., Flood mapping using hydraulic modeling and Sentinel-1 image: Case study of Medjerda Basin, northern Tunisia. The Egyptian Journal of Remote Sensing and Space Science, 23 (3), 303-310. https://doi.org/10.1016/j.ejrs.2020.03.001, 2020.

3. Arturo, S. L., Christopher, G., Controlling HEC-RAS using MATLAB. Environmental Modelling \& Software, 84, 339-348. https://doi.org/10.1016/j.envsoft.2016.06.026, 2016.

4. Costabile, P., Costanzo, C., Ferraro, D., Macchione, F., Petaccia, G. Performances of the New HEC-RAS Version 5 for 2-D Hydrodynamic-Based Rainfall-Runoff Simulations at Basin Scale: Comparison with a State-of-the Art Model. Water. 12(9), 2326. https://doi.org/10.3390/w12092326, 2020.

5. Dasallas, L., Kim, Y., An, H., Case Study of HEC-RAS 1D-2D Coupling Simulation: 2002 Baeksan Flood Event in Korea. Water, 11(10), 2048. https://doi.org/10.3390/w11102048, 2019.

6. Deshays, R., Segovia, P., Duviella, E., Design of a MATLAB HEC-RAS Interface to Test Advanced Control Strategies on Water Systems. Water, 13(6), 763. https://doi.org/10.3390/w13060763, 2021.

7. Dysarz, T., Application of Python Scripting Techniques for Control and Automation of HEC-RAS Simulations. Water, 10(10), 1382. https://doi.org/10.3390/w10101382, 2018.

8. Garcia, M., Juan, A., Bedient, P., Integrating Reservoir Operations and Flood Modeling with HEC-RAS 2D. Water, 12(8), 2259. https://doi.org/10.3390/w12082259, 2020.

9. Gilja, G., Harasti, A., Fliszar, R. D., CAN-A MATLAB Function for Generation of a HECRAS-Compatible Drainage Canal Network Model. Computation, 9(5), 51. https://doi.org/10.3390/computation9050051, 2021.

10. Huţanu, E., Mihu-Pintilie, A., Urzica, A., Paveluc, L.E., Stoleriu, C.C., Grozavu, A., Using 1D HEC-RAS Modeling and LiDAR Data to Improve Flood Hazard Maps Accuracy: A Case Study from Jijia Floodplain (NE Romania). Water, 12(6), 1624. https://doi.org/10.3390/w12061624, 2020.

11. Khattak, M.S., Anwar, F., Saeed, T.U., Mohammed Sharif, Khurram Sheraz \& Anwaar Ahmed. Floodplain Mapping Using HEC-RAS and ArcGIS: A Case Study of Kabul River. Arab J Sci Eng 41, 1375-1390. https://doi.org/10.1007/s13369-015-1915-3, 2016.

12. Kovacs, S., Kiss, A., Szekeres J., Experiences in application of HEC-RAS model under circumstances of flood waves. In: Schanze, J., Zeman, E., Marsalek, J. (eds) Flood Risk Management: Hazards, Vulnerability and Mitigation Measures. NATO Science Series, 67. Springer, Dordrecht. https://doi.org/10.1007/978-1-4020-4598-1_4, 2006.

13. Kumar, N., Kumar, M., Sherring, A., Shakti, S., Ajaz, A., Deepak, Lal., Applicability of HEC-RAS 2D and GFMS for flood extent mapping: a case study of Sangam area, Prayagraj, India. Model. Earth Syst. Environ. 6, 397-405. https://doi.org/10.1007/s40808-019-00687-8, 2020.

14. Mohsin, J. B., Muhammad, U., Raheel, Q., Landslide dam and subsequent dam-break flood estimation using HEC-RAS model in Northern Pakistan. Natural Hazards, 65, 241-254, 2013.

15. Namara, W.G., Damisse, T.A., Tufa, F.G., Application of HEC-RAS and HEC-GeoRAS model for Flood Inundation Mapping, the case of Awash Bello Flood Plain, Upper Awash River Basin, Oromiya Regional State, Ethiopia. Model. Earth Syst. Environ. https://doi.org/10.1007/s40808-021-01166-9, 2021. 
16. Natarajan, S., Radhakrishnan, N., An Integrated Hydrologic and Hydraulic Flood Modeling Study for a Medium-Sized Ungauged Urban Catchment Area: A Case Study of Tiruchirappalli City Using HEC-HMS and HEC-RAS. J. Inst. Eng. India Ser. A 101, 381-398. https://doi.org/10.1007/s40030-019-00427-2, 2020.

17. Ongdas, N., Akiyanova, F., Karakulov, Y., Muratbayeva, A., Zinabdin, N., Application of HEC-RAS (2D) for Flood Hazard Maps Generation for Yesil (Ishim) River in Kazakhstan. Water, 12(10), 2672. https://doi.org/10.3390/w12102672, 2020.

18. Parhi, P.K., Flood Management in Mahanadi Basin using HEC-RAS and Gumbel's Extreme Value Distribution. J. Inst. Eng. India Ser. A 99, 751-755. https://doi.org/10.1007/s40030-018-0317-4.

19. Pathan, A.I., Agnihotri, P.G., Application of new HEC-RAS version 5 for 1D hydrodynamic flood modeling with special reference through geospatial techniques: a case of River Purna at Navsari, Gujarat, India. Model. Earth Syst. Environ. 7, 1133-1144. https://doi.org/10.1007/s40808-020-00961-0, 2018, 2021.

20. Rangari, V.A., Umamahesh, N.V., Bhatt, C.M., Assessment of inundation risk in urban floods using HEC RAS 2D. Model. Earth Syst. Environ. 5, 1839-1851. https://doi.org/10.1007/s40808-019-00641-8, 2019a.

21. Rangari, V.A., Sridhar, V., Umamahesh, N.V., Ajey, K. P., Floodplain Mapping and Management of Urban Catchment Using HEC-RAS: A Case Study of Hyderabad City. J. Inst. Eng. India Ser. A 100, 49-63. https://doi.org/10.1007/s40030-018-0345-0, 2019b.

22. Salman, A., Hassan, S.S., Khan, G.D., Muhammad, A.G., Aftab, A. K., Khurram, S., HEC-RAS and GIS-based flood plain mapping: A case study of Narai Drain Peshawar. Acta Geophys. 69, 1383-1393. https://doi.org/10.1007/s11600-021-00615-4, 2021.

23. Sathya A., Thampi S.G., Flood Inundation Mapping of Cauvery River Using HEC-RAS and GIS. In: Singh, R.M., Sudheer, K.P., Kurian, B. (eds) Advances in Civil Engineering. Lecture Notes in Civil Engineering, 83. Springer, Singapore. https://doi.org/10.1007/978-98115-5644-9_2, 2021.

24. Tamiru, H., Wagari, M., Machine-learning and HEC-RAS integrated models for flood inundation mapping in Baro River Basin, Ethiopia. Model. Earth Syst. Environ. https://doi.org/10.1007/s40808-021-01175-8, 2021.

25. Urzică, A., Mihu-Pintilie, A., Stoleriu, C.C., Cîmpianu, C.I., Huţanu, E., Pricop, C.I., Grozavu A., Using 2D HEC-RAS Modeling and Embankment Dam Break Scenario for Assessing the Flood Control Capacity of a Multi-Reservoir System (NE Romania). Water, 13(1), 57. https://doi.org/10.3390/w13010057, 2021.

26. Yalcin, E., Assessing the impact of topography and land cover data resolutions on twodimensional HEC-RAS hydrodynamic model simulations for urban flood hazard analysis. Nat Hazards 101, 995-1017. https://doi.org/10.1007/s11069-020-03906-z, 2020.

27. Zainalfikry, M.K., Ab, G. A., Zakaria, N.A., Chan, N.W., HEC-RAS One-Dimensional Hydrodynamic Modelling for Recent Major Flood Events in Pahang River. In: Mohamed, Nazri F. (eds) Proceedings of AICCE'19. AICCE 2019. Lecture Notes in Civil Engineering, 53. Springer, Cham. https://doi.org/10.1007/978-3-030-32816-0_83, 2020. 